\title{
LAWYER OPINION ON LEGAL EDUCATION: A SOCIOLOGICAL ANALYSIS*
}

\author{
LEONARD H. GOODMAlli and \\ RICHARD W. RABINOWITZ I†
}

TIMre, rivers, and articles on legal education flow on ad infinitum and, in the case of the last, sometimes ad nauseam. It would seem that almost every conceivable point of view concerning legal education has been espoused in the voluminous literature created by eminent members of the judiciary, by some of our outstanding practitioners and, particularly, by the legal educators themselves. Therefore, lest the reader despair, we hasten to point out that we make no plea for any particular modification of the curriculum of the law school; we do not propound a panacea for legal education which would solve the problems involved in training lawyers for diverse functions. This is simply a research paper in which some empirical data and some of their implications for legal education are discussed.

\section{The Controversy Over Legal Education}

One of the principal trends in contemporary thought concerning legal education is that which emphasizes the policy-making function of the attomey both in public positions and in private practice and which correlatively advocates training in the utilization of "social science skills" for the formulation of policy and for the effective implementation of "social values." This school of thought is, of course, best exemplified in the writings of Lasswell and McDougal, who have been its most articulate spokesmen. ${ }^{1}$ In a recent expression of opinion on the subject, Professor McDougal urges the law school to take cognizance of the trend toward interdependence among nations, affirms the concept of the world community, and counsels the law school to devote its energy to the creation of the institutions, doctrines, and practices for the realization of "community values."2 Leon Keyserling has argued that

*The data for this article are taken from "The Study of the Lawyer and the Community" directed by Walter I. Wardwell and Arthur L. Wood, under the sponsorship of The Survey of the Legal Profession of the American Bar Association. The analysis and conclusions of this article are the responsibility of the present authors. The latter wish to thank Professors Wardwell and Wood for their kindness in permitting this use of those data.

instructor in Sociology \& Antropology, University of Delaware.

ii Research Associate; Harrard Law School.

1. The fullest exposition of this position is found in Lasswell \& MreDougal, Legal Education and Public Policy: Professional Training in the Public Interest, 52 Yale L.J. 203 (1943).

2. McDougal, The Law School of the Future: From Legal Realism to Policy Science in the World Community, 56 YaLE L.J. 1345 (1947). 
the bar, in its legislative, political, and courtroom activities, to a grenter extent than the bench, makes law. He concludes that the law school should provide the kind of social science background which would facilitate student comprehension of the social setting as well as the social and economic implications of law in a "transitional social order." G.W. Johnston has observed that "today's lawyers have a social responsibility to assume a position of leadership in the affairs of mankind," and proposes that students be given training which will provide them with knowledge of "political, economic, social and human values" with the reservation that this be a "by-product of instruction in what we now know as strictly 'legal' courses." Fuchs, ${ }^{,}$Beutel, ${ }^{\circ}$ Cheatham, ${ }^{7} \mathrm{~J}$. Cohen, ${ }^{8}$ and Harno, ${ }^{0}$ among others seem to be in general agreement that, in view of the extent and importance of the lawyer's participation in legislative and administrative activity, he should be trained in the law school to use social science materials and techniques for the fulfillment of his role as a responsible public servant. Even W. Barton Leach, whom one would scarcely identify with the Lasswell-McDougal philosophy of legal education, has indicated that he is favorably inclined toward the study of "Policy Science in the world community," with the stipulation that it be undertaken during summer sessions. ${ }^{10}$

Another major position is that which emphasizes the "client-caretaking" function of the attorney and reaffirms the law school's obligation to train the student in the skills necessary to that function. One variant of this position, perhaps best represented by Dean Pound, ${ }^{11}$ acknowledges the importance of social science training but denies it a place in the law school curriculum, maintaining that the primary objective of the law school should be the production of technically competent practitioners. Another variant is found in the position of Judge Frank who stresses the need for training in the skills employed in the trial court and who points out that "our law schools should once more bring themselves into close contact with what clients need and what courts and lawyers actually do."12 Although he would consent to the inclusion of social science materials in law courses, he would have them function as instrumentalities for producing more effective trial attorneys

3. Keyserling, Social Objectives in Legal Education, 33 Colun. L. Rev. 437 (1933).

4. Johnston, Sociological and Non-Legal Courses, 23 RockY Mr. L. REv. 71, 72, 74 (1950).

5. Fuchs, Legal Education and the Public Interest, 1 J. LEG. ED. 155 (1948),

6. Beutel, Changes Necessary in the Law Curriculum to Meet the Role of the Lawyers in Modern Society, 9 LAw. GuInd REv. 89 (1949).

7. Cheatham, The Law Schools and the Government Service, 22 B.U.L. Rev. 248 (1942).

8. Cohen, Crisis in Legal Education, 15 U. CHI. L. Rev. 588 (1948).

9. Harno, Disciplines in the Training of a Lareyer, 22 B.U.L. Rev. 254 (1942).

10. Leach, Property Law Tanght in Tzo Packages, 1 J. Leg. Ed. 28 (1948).

11. Keyserling, supra note 3 , at $450 \mathrm{n}$. sets forth a number of Dean Pound's expressions of opinion on the subject of legal education.

12. Frank, A Plea for Lawyer-Schools, 56 YALE L.J. 1303, 1313 (1947). 
since, in his view, the primary responsibility of the law school is to train for activity in this domain.

We will not attempt to enumerate further the various subtypes of these positions on legal education nor to ascribe ascendancy to any one of them. Our purpose is to indicate that to a large extent the particular recommendation reflects the vantage point of its author. If it were agreed that law school curricula should be primarily oriented to the day-to-day requirements of law graduates, one would want to know the extent to which the published views are representative of lawyer opinion on the subject. Or, one might ask, as Llewellyn did in $1935:^{13}$ What, in fact, do lawyers do? How many lawyers are engaged to what extent in what kinds of policy-making activities? How many attorneys are full time general practitioners? In short, one thing needed is a systematic statistical inventory of the roles now being perforned by the population of law school graduates. Unfortunately, since Llewellyn asked the question, only partial answers have appeared, among them Esther L. Brown's excellent monograph on the lawyer in government. ${ }^{14}$ Until role inventory data or a large-scale survey of lawyer opinion or both are available, the controversy over the "ought" of legal education must continue to be largely biased, discursive, and hortatory. ${ }^{15}$

\section{LAWYER OPINION}

The data and discussion presented here are more on the order of an opinion survey than a role inventory. They fall very far short of what is required, but it is hoped that those who make decisions bearing upon the general problem of legal education will nevertheless find them useful. These data were obtained from attorneys by means of interviews conducted in the course of field work for the "Study of the Lawyer and the Community" in a Southern metropolis ("Southmet") and in a New England town ("Northtown"). They consist of the following: (1) general comments on legal education made by "Northtown" respondents, (2) responses from both "Northtown" and "Southmet" attorneys to a question (referred to hereafter as the "schedule question") dealing with policy-making emphasis in legal education, and (3) certain background and attitudinal data, used to interpret responses

13. Llewellyn, On What Is Wrong with So-Called Legal Education, 35 CoLuas. L. REv. 651, 655 (1935).

14. Brown, Lawyers, Law Schools and the Public Service (1948). One of the few specialized lawyer roles which has been touched upon in the literature is that of the government attorney. See, e.g., Marx, The Lawyers' Role in Public Administration, 55 YALE L.J. 498 (1946) ; Cheatham, supra note 7; Gellhorn, The Law Schools' Responsibility for Training Public Serzants, 9 U. CHI. L. Rev. 469 (1942); Reuss, The Loutyer in the OPA, 10 Axs. L. Schoor Rev. 23 (1942).

15. A convenient summary of the history and present state of legal clucatiun in the United States will be found in Harso, Legal Education in tme United States (1953). 
to the "policy-making in education" question.10 Before discussing these dati, a few words concerning the respondents would seem to be in order.

Typically, these individuals are not the law school graduates about whose educational needs the articles on legal education are written. They are not the "architects of social change" with whom those oriented toward policymaking education are concerned, nor are they, by and large, the highly specialized experts in corporate law, patent law, trial work or the like. They do not have the perspective of the member of the appellate court who spends most of his professional time dealing with problems of major import to the community. These members of the bar have little opportunity or inclination for speculation concerning the underlying coherence-or lack of it-in any specialized field with which they may be momentarily concerned. They are practitioners who do most of their research for the particular case at hand with an eye toward determining the rule of the jurisdiction and not toward synthesizing decisions in a multiplicity of jurisdictions. Typically, they are the practitioners who go to court only occasionally, who never participate in a railroad reorganization, never advise on large-scale financing, and but once in their professional careers, if then, have the opportunity to draw a will for a member of their community's "upper-upper" set. In brief, they are the attorneys who handle real estate closings, get the truck drivers and salesladies their divorces, handle the contractual disputes between retailers and wholesalers, probate small and medium-sized estates and negotiate settlement of tort claims with insurance adjustors. They are unlikely to encounter any problem which would present a "beautiful case" for clissection in the classroom. What do these lawyers, first of all, think of their own legal training?

\section{The Small Town Lazeyer on Legal Education}

In order to suggest part of the answer to this question, we present a sampling of the various spontaneous comments given by the New England respondents prior to the introduction of the specific question on policy-making training in the law school. No claims are made for the representativeness of these comments; they are presented because such views are not frequently recorded in law journals and because they may contain valuable leads.

The salient feature of these comments is their almost uniformly unflattering criticism of law school training. Indeed, apart from those favorable comments concerning the role of the law school in training for public responsibility made in response to the schedule question, only a scant handful reflected a favorable attitude toward their legal education. For example, one attorney mentioned the favorable impression made upon him by a professor's discussion of the problem of ethics. Another commented favorably upon the

16. Data were obtained from a forty percent representative sample of the lawyers in the Southern city and from all but two of the attorneys in the New England town. Additional information concerning the characteristics of the lawyers and the communities may be found in a forthcoming publication by Professors Wardwell and Wood. 
fact that the law school he had attended provided its students with an opportunity to take part in legal aid work. Nonetheless, undue significance must not be attached to the paucity of praise; spontaneity in conversation may somehow be associated with a proneness to adverse criticism.

Adverse criticism was directed, in the first place, at the scope and quality of technical training. ${ }^{17}$ This is a theme familiar to the legal educator, so that it need not be spelled out in detail here. Briefly, the practitioners interviewed, both those favoring and those opposed to increased emphasis on training for public responsibility in the law school, desired that case-book study be de-emphasized and more attention given to what may be called the clinical aspects of training. ${ }^{18}$ Many small town practitioners felt that the law school neither prepares graduates to utilize procedural mechanisms nor trains them to function in the courtroom in such a way that they are able to apply to the situations encountered there the vast amount of substantive law theory with which they have become familiar. Thus, one young practitioner, when asked whether or not he had encountered difficulty in getting started in practice, replied:

"Yes, knowing what to do and how to do it. Legal matters were not a problem, but procedures, drawing up complaints, writs, motions, what motions to draw at what time, how to react in court in front of a judge, the practice in each court, how to size up a case, avoid being outbluffed by older attorneys, how to negotiate with insurance adjustors (they try to buy you off for a small amount)-were all hard to get on to. A couple of older attorneys here helped me out. They gave me advice and went to court with me the first few times."

Another attorney, having stated his general satisfaction with law as a career, qualified his comment in these words:

"[B] ut you should be better prepared. There should be more exhaustive study of procedure, more thorough and practical knowledge of evidence, more moot court work to give the prospective attorney a chance to think on his feet. You have to learn to radiate confidence. The real problem is how to make the client believe you have the capacity when there are so many things you don't know."

It will be noted that these attorneys related competence in technical areas to problems of social interaction ${ }^{10}$-in one case, interaction with the judi-

17. In the fifty-one criticisms of legal education given in response to the schedule question by those who answered either positively or negatively, it was maintained that greater emphasis should be given by the school to the "practical aspects" of Law, to "technical training," and to procedure. Five of the comments explicitly stated the need for more courtroom experience.

18. Of course, in the literature clinical training is frequently advocated. See, c.g., Miller, Clinical Training of Law Students, 2 J. LEc. Ev. 298 (1950) ; Bradway, Eddtcation for Law Practice: Law Students Can Be Gizen Clinical Experience, 34 A.B.A.J. 103 (1948) ; Frank, supra note 12.

19. Particularly in the law there is too much overlap between "technieal" and "social" skills to permit a precise distinction. For example, it would be rather diffeult 
ciary, other attorneys, and adjustors, in the other, interaction with the judiciary and with clients. Since problems of this sort are rarely discussed either privately or in print, they were pursued further with a number of other practitioners who were interviewed a second time during the course of the field work. Generally, they were asked whether or not they felt that their law school training had prepared them adequately for dealing with problems arising from the social interaction of lawyer and client. Only one indicated that he had been adequately prepared to handle such matters. The rest gave replies similar to those above. In general, their remarks indicated that they did not know how to go about structuring and controlling the professional relationship. They asserted that they were unprepared to deal with clients in an effective manner, that they had not anticipated the fact that a client's story could be distorted by his emotional involvement in the problem situa. tion, and that they had been unaware of the possibility of their own affective involvement in the client's problems. Several respondents commented upon the tendency of the young attorney to place inordinate confidence in the client's presentation of the "facts." For example:

"When I started in practice, I was more likely to be taken in. If my man said he was right, I was certain of it. The hardest thing to learn in this business is not to be carried away by the client's story. [Is this something you have to learn?] Definitely. [Did you ever anticipate while you were in law school that these things were involved?] No; in law school it never occurred to me."

During his interview, another attomey remarked that "the embryonic lawyer doesn't know how to approach people. It takes a little time to get on to the fakers."

Several other respondents made it clear that at no time during their legal education had they been made aware of problems involving the use of "social skills" in performing the professional role. When asked whether he had anticipated encountering an emotionally distraught client, one practitioner replied:

"No, not at all. It's a needed feature of law education. They didn't indicate the problem of dealing with people. The average practitioner needs it. It's a genuine blindspot. You'll have to do a lot of case reading later anyway if you're a conscientious practitioner."

However, a lawyer who had had an opportunity to do legal aid work in law school, when asked if he had been prepared to deal with the emotionally disturbed client, asserted that he had indeed anticipated the problem:

"I think I got it in Legal Aid, for one thing. As a matter of fact, I think that's about the only thing I got from it. It was useful."

In striking contrast to the replies from lawyers with law school backgrounds were the responses of two members of the bar who were admitted

to argue that the ability to persuade a client to "cop a lesser plea" is either more "technical" or more "social." 
to practice after receiving office training. One spoke of his legal education in the following terms:

"Remember that I studied in an office. I was a lawyer from the first day I went to study for $X$. Day by day, I did everything. I thought I was a lawyer. I saw how he greeted clients; I shared the grief over lost cases; I attended conferences and heard discussions about fees. By the time I was in practice for myself, I thought I knew the approach .... When I got admitted [to the bar] I felt confident; I felt that I could practice successfully; I thought I knew the basic principles of contracts. torts and procedure and enough evidence to try a simple case . . .."

The other office-trained attorney maintained:

"I didn't find it difficult getting started. I knew procedure, how to draw papers. Things like the mechanics of practice came easier to me. The theoretical end came much harder."

Both indicated that they had had no particular difficulty handling routine interpersonal problems.

Several lawyers suggested ways to overcome these problems: more required moot court work in law school, a required clerkship, or other apprenticeship analogous to the medical internship. To cite just one example of such responses:

"[T]he schools should enlarge the practical aspects. I think a lawyer should know through practical experience the way a doctor who wants to be a surgeon does-by working in a hospital. First he just stands around the operating room, later he gets to do the sutures, later the operation. It's a long process. The law student doesn't even know what a writ looks like. An apprenticeship would be important."

In the absence of some systematic, formalized training as apprentice, the fledgling attorney must meet the problems mentioned in a hit-or-miss fashion, by entering a firm or by associating informally with more experienced lawyers. The importance of the established practitioner as a socializing agent was illustrated by one respondent:

"I thought of opening my own office. Immediately I became frightened. Actual practice is so strange. It would have been particularly difficult for me because I didn't know any lawyers well enough to call them to advise me...."

It is not likely that lawyers who maintain opinions along the lines of those quoted above-unless of an unusually sanguine and philosophical naturewould take kindly to at least the first part of Dean Griswold's recent admonition to the law schools:

20. It may well be that the law school's relative neglect of the "practical aspects" of legal practice has contributed much to the apparent trend away from solo practice and toward group practice, since the firm or association constitutes an alternative or supplementary educational institution which fills the gap left by the schools. 
"Whatever they do in this area [of practical education], the law schools must be careful to keep first things first, to remember that they are not training lawyers primarily for the first month out of law school, but for twenty years and more out-for a professional career that normally lasts a lifetime. They must remember, too, that one of their most important functions is not the training of journeyman practitioners but rather the training of the men who must be leaders and set the standards and tone and provide the imaginative insights for an important part of the community for many years after leaving law school."21

Lawyers like the respondents might argue that certain changes could be made without converting to "purely practical education" and without sacrificing either legal theory or a public leadership emphasis; that modifications could be introduced without necessarily "turning the law schools into clinics"; and that experiments could be performed which did not degenerate into "sideshows." If their felt needs are real and if the needs of law graduates are to be taken as criteria for planning legal education, these needs might well be given more serious, objective and, preferably, scientific study.

\section{Should the Schools Place More Emphasis on Policy-Making Education?}

We shall now examine in some detail the respondents' opinions regarding the more specific problem of policy-making training in legal education. Data obtained from both "Northtown" and "Southmet" respondents are presented, but attention is given primarily to the latter because, generally, the relationships among factors are more significant statistically where the "Southmet" bar is concerned. However, as will be seen, the "Northtown" data very largely bear out the "Southmet" as far as direction of relationships goes.

The question which sought to evoke opinion concerning emphasis on policymaking education, the schedule question, was phrased as follows:

"In your opinion, should law schools assume a larger responsibility for instructing lawyers on broad social questions so that they can function better in positions of public responsibility, e.g., in designing legislation or in policy-making positions, etc. ?"22

21. Griswold, The Future of Legal Education, CoNFERENCE ON LAW AND LEGA. Education 104-05 (Chicago Law School, Conference Series No. 1.1, 1952).

22. A few comments should be made about this question: (1) It stresses mainly one aspect of the problem, the quantitative, i.e., whether there should be more or less policy emphasis. It does not put in issue the content of such emphasis. (2) The question may appear to be somewhat ambiguous in that "larger responsibility" may mean anything from more than $n o$ responsibility in the matter to more than the responsibility assumed by, say, the Yale Law School. For one thing, however, the mere fact that definite relationships between the response to this question and other variables were found leads to the conclusion that this was not a serious fault. Secondly, it was ascertained that the answer to the question bore very little relation to the type of school the respondent had attended. In fact, lawyers who had attended the schools (e.g., Yale, Virginia, Harvard, Columbia) where, generally, a public responsibility emphasis prevails, exhibited a slight tendency to respond in the negative to the question. It would seem, then, that the various 
To begin with, it should be pointed out that most of the respondents in each community regarded legislative and other policy-making activity as a component of the lawyer role. This is clear from the content of the negative responses to the schedule question-some of which, for example, maintain that formal training for this activity is not required-and from the fact that only five respondents voluntarily expressed opinions that policy-making activity is not part of the lawyer role. Those who answered the schedule question affirmatively, favoring more policy-making education, a fortiori, believe it to be part of the lawyer role. However, we do not know the extent to which this consensus denotes the conviction that policy-making activities should be part of the lawyer's role or simply describes the fact that lawyers do perform such functions.

But when the question of the law school's part in providing training for policy-making activity on a larger scale is raised, the happy unanimity among respondents dissipates. As may be seen in Table I below, 217 attorneys in both communities gave distinct, qualified or unqualified answers to the schedule question. Of these, 109 indicated that the law school should provide more instruction "on broad social questions" in order that their graduates might "function better in positions of public responsibility," while 108 felt that they should not. Furthermore, this nearly even split occurred in each community.

TABLE I

Distribution of Responses to Schedule Question by Communily

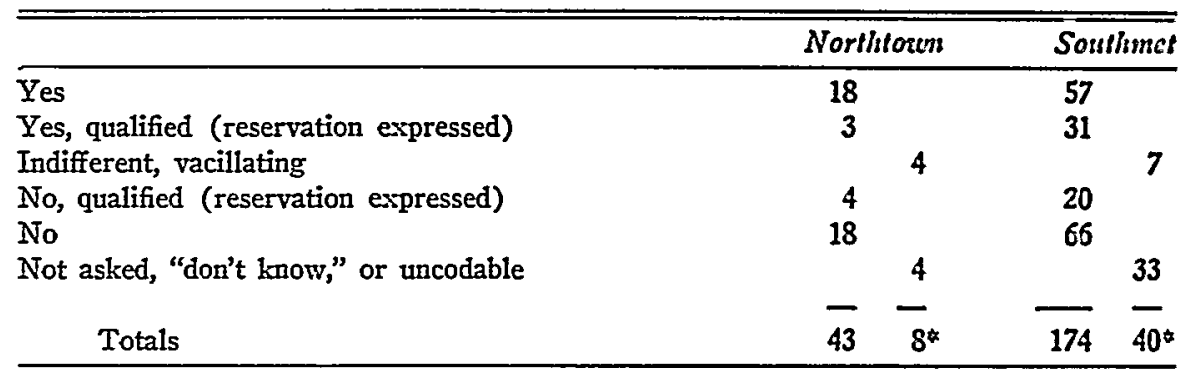

*Respondents represented in these two totals are excluded from all subsequent tables and discussion.

This response may not be interpreted to mean that fifty percent of the respondents rejected the idea of formal training for public responsibility and policy-making activity. Not only did the great majority of negative responses recognize the lawyer's involvement in this activity, but a majority stated that some formal training for these purposes was desirable. Twenty-seven of the

responses are essentially comparable. (3) The question is "loaded" in that it carrics the implication that such instruction does in fact enable the lawyer to "function better in positions of public responsibility." However, the form of the question appears to have biased the responses very little. 
negative replies were given by respondents who thought that this training should be provided at the college level. ${ }^{23}$ If these twenty-seven are grouped with those who have indicated that such training should form a greater part of legal education, sixty-three percent of the respondents are of the opinion that the prospective attorney should receive such training at some point in his academic career. Should not, then, these twenty-seven lawyers be grouped with those who answered in the affirmative to the schedule question? No. Although they share the belief that this formal training is desirable, these twenty-seven have very little else in common with those who respond in the affirmative to the schedule question. They are much closer in terms of a number of characteristics to those who respond in the negative on other grounds. In fact, if their opposition to training for public responsibility in the law school is measured in terms of certain characteristics (employed as indices), the twenty-seven turn out to be much more "negative" than the "average" respondent who falls into the negative category. 24 This is a preliminary indication of the fact that the original distribution of responses to the schedule question is very far from spurious and that there was a balance of factors which precipitated this particular distribution once the schedule question was asked. We now turn our attention to a few of these factors.

\section{Response to Schedule Question and Social-Political Orientation}

To almost any lawyer, the question of altering the pattern of legal edication is an important one. In view of the various technical problems alone, it might well be regarded as a critical question. The lawyer, then, would

23. The same view is frequently found in the periodical literature. Gellhorn, supra note 14 , at 472 , maintains that knowledge of the law-related social sciences should be acquired in the university. Likewise, Fuchs, Legal Education and the Public Intcrest, 1 J. LEG. ED. 155, 163-65 (1948), believes that pre-law training in logic, ethics, history, and the social studies is desirable, at least until they can be integrated into the law school curriculum itself. On the other hand, Johnston, Sociological and Non-Legal Courses, 23 Rocky MT. L. REv. 71, 72 (1950), is of the opinion that the colleges are not training students for policy-making and, furthermore, they are unlikely to do so. The same dim view is held by Keyserling, Social Objectives in Legal Education, 33 CoLum. L. REv. 437,449 (1933), who states that the college is not the place for training in the social and economic implications of legal problems because these implications "can be understood only after an intimacy with their precise nature," an intimacy which is acquired, of course, in the law school itself.

24. As will be demonstrated, those who gave positive replies to the schedule question differed significantly from those who answered negatively in regard to these variables: (1) political preference; (2) proportion of income derived from law practice; (3) status of family of orientation; (4) firm membership; (5) political activity. The group of 27 differed more than the other "negative respondents" from the "positive respondents" in regard to (1) and (2); they differed as much as the other "negative respondents" in regard to (3); they differed slightly less in regard to (4) insofar as more of them were independent practitioners. The only variable upon which they differed significam!ly less than the other "negative respondents" was political activity (5) : far more of them, proportionally, had never participated in politics. Possibly this may be accounted for by the fact that they clustered heavily in the younger age bracket. 
not be very likely to give his views casually or superficially; on the contrary, his response would probably be thoughtful and would express some of his basic convictions and values. What kinds of convictions and values? The debate over legal education may be fitted quite comfortably within the larger framework of social-political ideological controversy. Concretely, the "policy-making school," judging from the articles published by its members, may be analytically identified with the ideology expressed in such terms as "public welfare," "liberalism," "governmental regulation," and "social planning"; likewise, the "client-caretaking school" may be associated with the ideology epitomized by "conservatism," "laissez-faire," "private interest," "free enterprise," and the like. But is the practicing attorney's opinion on increasing policy-making training in law school similarly related to his personal social-political orientation? In order to estimate this relationship, three indices of social-political orientation were used: (1) attitude toward increased governmental activity: (2) party preference in the 1948 presidential election; and (3) socio-economic background.

At the time of this study, both communities were confronted with the possibility of extension of governmental activity of roughly comparable nature. In one community, the issue was the extension of municipal enterprise in the form of public management of a utility; in the other, it involved the roles to be played by federal and state governments in establishing heavy industry in the area. One may see in Table II that the "Southmet" respondents who farored an extension of governmental activity tended to respond to the schedule question in the affirmative. On the other hand, those who indicated opposition showed a slight inclination, as a gruup, to oppose any increase in emphasis on education for public responsibility in the training of the attorney. While there is no significant degree of association between these two variables as far as the New England lawyers are concerned, the distribution approaching "zero relationship," it will nevertheless be observed that the percentages go in the same direction as those representing the responses of their Southern brothers.

TABLE II 26

Response to Schedule Question and Attitude touard Extension of Goucrumcnt Aelizity

\begin{tabular}{|c|c|c|c|c|c|}
\hline \multicolumn{3}{|c|}{ Northtowon } & \multicolumn{3}{|c|}{ Southmel } \\
\hline $\begin{array}{l}\text { Schedule } \\
\text { Question } \\
\text { Response }\end{array}$ & $\begin{array}{c}\text { Oppose Gov't } \\
\text { Activity }\end{array}$ & $\begin{array}{c}\text { Favor Gov't } \\
\text { Activity }\end{array}$ & $\begin{array}{l}\text { Schedile } \\
\text { Question } \\
\text { Response. }\end{array}$ & $\begin{array}{c}\text { Oppose Gov'l } \\
\text { Aclizily }\end{array}$ & $\begin{array}{l}\text { Fovor Gor' } \\
\text { Actizily }\end{array}$ \\
\hline $\begin{array}{l}\text { Yes } \\
\text { No }\end{array}$ & $\begin{array}{l}44 \% \\
56\end{array}$ & $\begin{array}{l}52 \% \\
48\end{array}$ & $\begin{array}{l}\text { Yes } \\
\text { No }\end{array}$ & $\begin{array}{l}-47 \% \\
53 .\end{array}$ & $\begin{array}{l}65 \% \\
35\end{array}$ \\
\hline $\begin{array}{l}\text { Totals } \\
\qquad \mathbf{x}^{2}=0\end{array}$ & $\begin{array}{c}100 \% \\
(16) \\
; \mathrm{P}<.70\end{array}$ & $\begin{array}{l}100 \% \\
(21)\end{array}$ & $x^{2}=$ & $\begin{array}{c}100 \% \\
(94) \\
4.02 ; \mathrm{P}<.05\end{array}$ & $\begin{array}{l}100 \% \\
(48)\end{array}$ \\
\hline
\end{tabular}

25. In this and in the subsequent tables, the degree of association between two variables is tested by means of Chi square, $\mathrm{X}^{2}$, which is a measure of the extent to which 
A very similar picture appears in Table III where response to the schedule question and political party preference are cross-tabulated. Again, however, the factors are not significantly associated in the "Northtown" case, although interestingly, four out of five "Northtown" Democrats answered the schedule question affirmatively. On the other hand, the association is validly established among the Southern lawyers. The "lumping" together of Dixiecrat and Republican deserves some comment: It seems safe to assume that those who defected from the Democratic ranks during the 1948 election campaign were of a more "conservative" political orientation than those who remained; in some respects at least, Dixiecrats appear to have been more like Republicans than like Democrats. Thus, we have the second indication of the influence of social-political orientation on the response to the schedule question, at least as far as the Southern attorneys go. ${ }^{28}$

TABLE III

Response to Schedule Question and Party Preference in 1948 Election

\begin{tabular}{|c|c|c|c|c|c|}
\hline \multirow[b]{2}{*}{$\begin{array}{l}\text { Schedule } \\
\text { Question } \\
\text { Response }\end{array}$} & \multicolumn{2}{|l|}{ Northtown } & \multicolumn{3}{|c|}{ Southmet } \\
\hline & $\begin{array}{c}\text { Dixiecrats and } \\
\text { Republicans }\end{array}$ & Democrats & $\begin{array}{l}\text { Schedule } \\
\text { Question } \\
\text { Response }\end{array}$ & $\begin{array}{l}\text { Dixiccrats and } \\
\text { Republicans }\end{array}$ & Democrats \\
\hline $\begin{array}{l}\text { Yes } \\
\text { No }\end{array}$ & $\begin{array}{l}45 \% \\
55\end{array}$ & $\begin{array}{l}80 \% \\
20\end{array}$ & $\begin{array}{l}\text { Yes } \\
\text { No }\end{array}$ & $\begin{array}{l}42 \% \\
58\end{array}$ & $\begin{array}{l}61 \% \\
39\end{array}$ \\
\hline Totals & $\begin{array}{c}100 \% \\
(33)\end{array}$ & $\begin{array}{l}100 \% \\
(5)\end{array}$ & Totals & $\begin{array}{c}100 \% \\
(85)\end{array}$ & $\begin{array}{c}100 \% \\
(61)\end{array}$ \\
\hline \multicolumn{2}{|c|}{$\mathrm{X}^{2}=.92 ; \mathrm{P}<.50$} & & \multicolumn{2}{|c|}{$\mathrm{X}^{2}=4.76 ; \mathrm{P}<.05$} & \\
\hline
\end{tabular}

a given frequency distribution is a departure from one which would show no relationship. The degree of relationship (or association-the terms are used interchangeably here) is expressed in terms of the probability $P$ of obtaining a $X^{2}$ value as large as or larger than any given value. Thus, for example, in a four-fold table a $\mathrm{X}^{2}$ value of 6.64 has a corresponding $P$ of .01 , which signifies that the given distribution departs from "zero association" to such an extent as would occur by chance only once in a hundred times. See McNearar, Psychological Statistics 193-200 (1949). Typically, in social science research, $P=.05$ is adopted as the minimum level of significance, although many considerations enter into the decision to adopt any value as the numerical criterion of significance, since obtaining values higher than .05 does not by any means indicate no association. In this paper, several tables are presented in which $\mathrm{P}$ values are much higher than .05 in order to show strong indications of association (which might be greater under conditions of more highly refined variables, larger samples, etc.). In such cases, the interpretation has been appropriately qualified.

26. Party preference is probably far less meaningful in terms of its established social-psychological correlates among the New England lawyers. Many more of them "should be" Democrats in terms of the usual indices. It may be that many of these cannot "afford" such identification because of such things as the necessity of recruiting Republican clients, pressure to obtain higher status, pressure to become acceptable to the more conservative, old-family, upper class, and Republican elements of the local bar, and the like. 
The relationship between social-political orientation and socio-economic status has been demonstrated repeatedly: "other things equal," low-income, low-prestige groups tend to be more "liberal" than upper-middle and upper class, particularly business, groups. Would it not be reasonable to expect, then, that the attorney whose social and political ideas and values were initially formed in a lower class family would be more likely to favor an increased emphasis on policy-making training in law school than one who received his early orientation in a higher class family? In other words, does the socio-economic status of the respondent's family of orientation ${ }^{27}$ indirectly affect his answer to the schedule question through its influence on his social-political orientation? To see whether or not this rather indirect relationship existed, the response to the schedule question was cross-tabulated with an index of the socio-economic status of the family of orientation, the latter consisting of the combined ratings of the respondent's father's occupational and educational statuses. The results appear in Table IV. It will be observed that the two variables are related in the same manner in both groups of respondents but that the degree of association is much higher as far as the "Northtown" attorneys are concerned, falling just short of the five percent level of significance. This is by no means conclusive, but taken together with the preceding evidence, it seems to be a fair indication that social-political ideas and values are causally related to the response to the schedule question.

TABLE IV

Response to Schedule Question and Status of Family of Orientation

\begin{tabular}{|c|c|c|c|c|c|}
\hline \multicolumn{3}{|c|}{ Northtowns } & \multicolumn{3}{|c|}{ Southinget } \\
\hline $\begin{array}{l}\text { Schedule } \\
\text { Question } \\
\text { Response }\end{array}$ & $\begin{array}{l}\text { Higher } \\
\text { Status Family }\end{array}$ & $\begin{array}{l}\text { Lower } \\
\text { Status Family }\end{array}$ & $\begin{array}{l}\text { Schedule } \\
\text { Question } \\
\text { Response }\end{array}$ & $\begin{array}{l}\text { Higher } \\
\text { Slatus Family }\end{array}$ & $\begin{array}{l}\text { Lower } \\
\text { Stotus Family }\end{array}$ \\
\hline $\begin{array}{l}\text { Yes } \\
\text { No }\end{array}$ & $\begin{array}{l}35 \% \\
65\end{array}$ & $\begin{array}{l}64 \% \\
36\end{array}$ & $\begin{array}{l}\text { Yes } \\
\text { No }\end{array}$ & $\begin{array}{l}45 \% \\
55\end{array}$ & $\begin{array}{l}56 \% \\
44\end{array}$ \\
\hline $\begin{array}{l}\text { Totals } \\
\qquad \mathrm{X}^{2}=3\end{array}$ & $\begin{array}{l}100 \% \\
(20) \\
.44 ; \mathrm{P}<.10\end{array}$ & $\begin{array}{l}100 \% \\
(22)\end{array}$ & $\begin{array}{l}\text { Totals } \\
\mathrm{X}^{2}=2.1\end{array}$ & $\begin{array}{r}100 \% \\
(100) \\
\text { 4; } \mathrm{P}<20\end{array}$ & $\begin{array}{l}100 \% \\
(71)\end{array}$ \\
\hline
\end{tabular}

\section{Response to Schedule Question and Features of the Professional Role}

The sociologist concerned with the interpretation of opinions and values must direct his attention to social structures. He looks for relationships between opinions on the one hand, and membership in groups, statuses, organizational activity, and the like, on the other. Thus, we ask: How do variations in the

27. The term "family of orientation" simply refers to the family into which the individual is born and in which he is socialized. For amplification, see Parsons, The Kinship System of the Contemporary United States, in Essays Im Socrobogrcal Tneomy 233-50 (1949). 
structure of professional behavior bear upon the divergence of opinion regarding the degree of emphasis on policy-making preparation in legal education?

The most apparent difference in the structure of law practice, that between the firm or the association and the independent practice, was reflected in the response of the "Southmet" attorneys to the schedule question. As indicated in Table V, those who were members of firms, whether partners or associates, tended to be opposed to any increase in emphasis on training for public responsibility in the law school, while most of the other members of the bar (including a few lawyers who were employed by either businesses or government) viewed the proposition with favor. What is the significance of this relationship? It is suggested, first of all, that the firm member is more likely than the "solo" practitioner to devote a major share of his professional time to corporate clients. It was found that, among the Southern attorneys, fully thirty-five percent of the firm members could be classified as "specialists" or "semi-specialists" in business or corporation law, whereas only nineteen percent of all other practitioners could be so classified. The skills traditionally conceived as being required for this type of work are rather far removed from the "social science-community values" framework, suggesting, perhaps, that the specific technical requirements of the role he plays influence the lawyer's opinions on legal education. Secondly, there is a greater likelihood that the firm member would identify his own interest with business interests and be generally oriented in terms of business norms and values. Insofar as "public responsibility" (in the ideological sense of the term) and (business-) client-caretaking are opposed in theory and in practice, he might be expected to incline toward the latter.

TABLE $\mathrm{V}$

Response to Sclredule Question and Organization of Practice

\begin{tabular}{|c|c|c|c|c|c|}
\hline \multirow[b]{2}{*}{$\begin{array}{l}\text { Schedule } \\
\text { Question } \\
\text { Response }\end{array}$} & \multicolumn{2}{|c|}{ Northtown } & \multicolumn{3}{|c|}{ Southmet } \\
\hline & $\begin{array}{c}\text { Firm } \\
\text { Member }\end{array}$ & $\begin{array}{c}\text { Non-Firm } \\
\text { Member }\end{array}$ & $\begin{array}{l}\text { Schedule } \\
\text { Question } \\
\text { Response }\end{array}$ & $\begin{array}{c}\text { Firm } \\
\text { Member }\end{array}$ & $\begin{array}{c}\text { Non-Firm } \\
M c m b c r\end{array}$ \\
\hline Yes & $40 \%$ & $54 \%$ & Yes & $39 \%$ & $61 \%$ \\
\hline No & 60 & 46 & No & 61 & 39 \\
\hline Totals & $\begin{array}{c}100 \% \\
(15)\end{array}$ & $\begin{array}{r}100 \% \\
(28)\end{array}$ & Totals & $\begin{array}{c}100 \% \\
(97)\end{array}$ & $\begin{array}{l}100 \% \\
(76)\end{array}$ \\
\hline \multicolumn{3}{|c|}{$\mathrm{X}^{2}=0.72 ; \mathrm{P}<.50$} & \multicolumn{3}{|c|}{$\mathrm{X}^{2}=5.06 ; \mathrm{P}<.05$} \\
\hline
\end{tabular}

These rather common sense observations are inadequate, however, and we must look for other structural sources of the differential response to the schedule question. In turning our attention to the variable, political participation, we find a complement to firm membership and a more fruitful interpretation.

As shown in Table VI, the pro-public responsibility and policy-making training respondents in "Southmet" actually engaged in more political activity 
than those opposed to such training. This fact is subject to opposite interpretations. Does it mean that the same values and convictions which dispose the attorney to favor more policy-making training in the law school also motivate him to engage in political activity, i.e., accept appointments, run for and hold office, perform party work? Or does it mean that those who are more active in the political field tend progressively to place more value in this activity and hence come to favor preparation for it?

TABLE VI

Response to Schedule Question and Political Participation

\begin{tabular}{|c|c|c|c|c|c|}
\hline \multicolumn{3}{|c|}{ Northtozenr } & \multicolumn{3}{|c|}{ Southmet } \\
\hline $\begin{array}{l}\text { Schedule } \\
\text { Question } \\
\text { Response }\end{array}$ & $\begin{array}{c}\text { No } \\
\text { Participation }\end{array}$ & $\begin{array}{c}\text { Some } \\
\text { Participations }\end{array}$ & $\begin{array}{l}\text { Sclicdule } \\
\text { Questions } \\
\text { Response }\end{array}$ & $\begin{array}{c}\text { No } \\
\text { Particifation }\end{array}$ & $\begin{array}{c}\text { Some } \\
\text { Parlicifation }\end{array}$ \\
\hline $\begin{array}{l}\text { Yes } \\
\text { No }\end{array}$ & $\begin{array}{l}50 \% \\
50\end{array}$ & $\begin{array}{l}51 \% \\
49\end{array}$ & $\begin{array}{l}\text { Yes } \\
\text { No }\end{array}$ & $\begin{array}{l}38 \% \\
62\end{array}$ & $\begin{array}{l}64 \% \\
36\end{array}$ \\
\hline $\begin{array}{l}\text { Totals } \\
\qquad \mathrm{X}^{2}=.2\end{array}$ & $\begin{array}{r}100 \% \\
(4) \\
24 ; \mathrm{P}<.70\end{array}$ & $\begin{array}{l}100 \% \\
(39)\end{array}$ & $\begin{array}{r}\text { Totals } \\
\mathrm{X}^{2}\end{array}$ & $\begin{array}{c}100 \% \\
(97) \\
=12.21 ; \mathrm{P}<\end{array}$ & $\begin{array}{ll} & 100 \% \\
& (76)\end{array}$ \\
\hline
\end{tabular}

In order to test the first alternative, "Political participation" was crosstabulated with two of the indices of social-political orientation: political party preference and socio-economic background. In both cases, the degree of association was quite low, the " $P$ " values being $<.30$ and $<.70$, respectively. A further effort was made to discover whether some pre-selective factor operated to push lawyers into political activity. It was thought that perhaps those who originally chose the law as their occupation in order to advance themselves in a political career or those whose motivation was a diffuse humanitarianism might have shown a greater tendency to engage in political activity. As it turned out, only fourteen percent of the 217 respondents indicated that either of these was their principal reason for taking up law, and they were not significantly inclined one way or the other on the matter of political participation. Judging from these bits of evidence, it would not appear that attitudinal or motivational factors operative prior to entry into law practice had very much effect on political participation. We therefore choose to pursue the second interpretation of Table VI.

It is probably true, as frequently observed, that many attorneys beginning private practice feel that they should make themselves "visible" to the public and raise their status in the public eye in order to attract a clientele. If an attorney engages in political activity for this purpose and attains a degree of success, he may attribute success to the activity and hence attach a high degree of importance to formal training for activity in "positions of public responsibility." This reasoning may be correct in varying degrees. Just as there are lawyers who obtain clients through publicity, political connections, 
and public service, there must be those whose political activities have alienated potential clients. The point, however, is that, correctly or mistakenly, many lawyers undertake political activity out of a belief in the necessity of doing so and subsequently affirm both the necessity and the desirability of policymaking training in law schools. It is also quite probable that many attorneys who are active politically become convinced of the inherent value (to themselves, to the community, or to both) as well as the instrumental value of their activity in this sphere.

The relationship between political activity and response to the schedule question comes into much sharper focus when it is seen in relation to the firm membership variable. Firm membership tends to be associated with a negative response to the schedule question while political participation is associated with a positive response. Is there then some relationship between membership in a firm and participation in politics? Table VII indicates thit in "Southmet" there is a tendency for firm members to stay out of politics. There does appear to be a distinct community difference on this point, however, which may be attributed to a difference in firm structures between "Southmet" and "Northtown." Only thirty-five percent of the "Northtown" bar were in firms as against fifty-six percent in "Southmet." Furthermore, with the exception of one five-man firm, the "Northtown" firms were two and three-man organizations. And the amount of specialization within the firms in the two communities was very different: sixty-nine percent of the "Northtown" firm members were classified as general practitioners as compared with only twenty-three percent of the "Southmet" lawyers falling into that category. While thirty-six percent of the "Northtown" lawyers classificd as specialists and semi-specialists were firm members, nearly two-thircls of the "Southmet" attorneys so classified were members of firms. Thus there appears to be greater similarity between the work situations of the firm member and the independent practitioner in the New England community than there is in "Southmet," and we should expect to find less differentiation in values and attitudes linked to the firm membership variable.

TABLE VII

Firm Membership and Political Participation

\begin{tabular}{|c|c|c|c|c|c|}
\hline $\begin{array}{l}\text { Political } \\
\text { Participation }\end{array}$ & $\begin{array}{c}\text { Northtown } \\
\text { Nor-Firm } \\
\text { Member } \\
\end{array}$ & $\begin{array}{c}\text { Firm } \\
\text { Member }\end{array}$ & $\begin{array}{l}\text { Political } \\
\text { Participation } \\
\end{array}$ & $\begin{array}{c}\text { Southmet } \\
\text { Non-Firm } \\
\text { Member }\end{array}$ & $\begin{array}{c}\text { Firmb } \\
\text { Member }\end{array}$ \\
\hline $\begin{array}{l}\text { None } \\
\text { Some }\end{array}$ & $\begin{array}{l}11 \% \\
89\end{array}$ & $\begin{array}{l}7 \% \\
93\end{array}$ & $\begin{array}{l}\text { None } \\
\text { Some }\end{array}$ & $\begin{array}{l}40 \% \\
60\end{array}$ & $\begin{array}{l}61 \% \\
39\end{array}$ \\
\hline $\begin{array}{l}\text { Totals } \\
\qquad \mathrm{X}^{2}=.02 ;\end{array}$ & $\begin{aligned} & 100 \% \\
& (28) \\
\mathrm{P} & <.90\end{aligned}$ & $\begin{array}{l}100 \% \\
(15)\end{array}$ & \multicolumn{2}{|c|}{$\begin{array}{cc}\text { Totals } & (77) \\
\mathrm{X}^{2} & =9.85 ; \mathrm{P}<.01\end{array}$} & $\begin{array}{l}100 \% \\
(97)\end{array}$ \\
\hline
\end{tabular}

There is at least one pressure, in addition to those mentioned above, which would tend to keep the firm member out of politics and, presumably, incline 
him to devalue formal training for policy-making activity and "public responsibility": the pressure to maintain political neutrality exerted by corporate clients who compete for public good will and by the firm itself when it is identified in the public eye with these clients. The lawyer in such a situation might view political activity as putting in jeopardy his standing both in the firm and vis-à-vis local business. If this were the case, he would probably not regard additional policy-making training as advantageous.

Finally, to what extent does adherence to or departure from the lawyer role proper influence response to the schedule question? The index of this variable is the proportion of income derived from the practice of law itself as compared with the proportion derived from insurance, accounting, business, and other "sidelines." Table VIII shows that those respondents who reported that less than seventy-five percent of their income came from their law practice exhibited some tendency to respond to the schedule question in the negative; those who reported that over seventy-five percent of their total income came from law practice tended to respond affirmatively. In neither group of lawyers was the degree of association between the two items suffciently high to be statistically conclusive; yet it is high enough to warrant an interpretation.

TABLE VIII

Proportion of Income Derived From Law and Response to Schedule Question

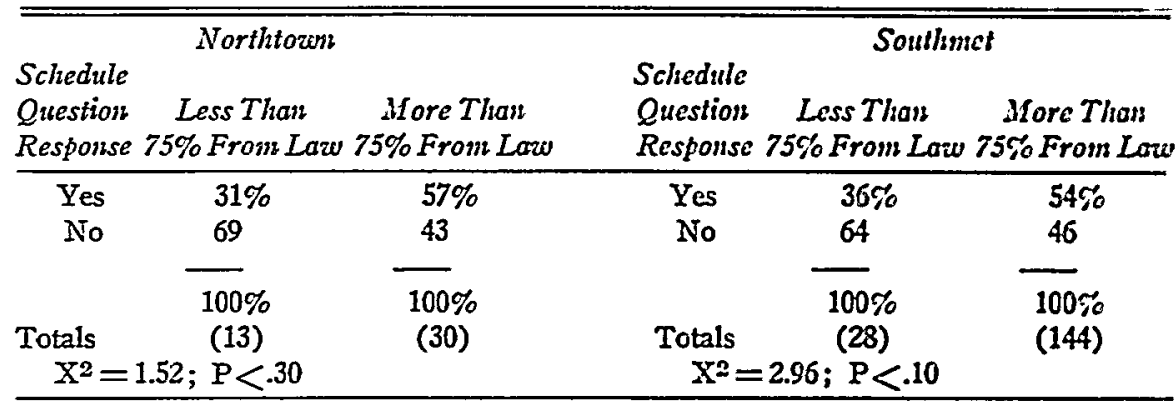

It is conjectured that there is a difference in definition of role between those who derive most of their income from legal practice and those who depend upon other sources of livelihood. The individual who is primarily a legal practitioner is more likely to have a broader definition of his occupational role than has the individual who engages in other business. The latter would probably tend to define his role in rather specific, technical terms and to make use of the more immediately practical and remunerative legal skills. He would probably not envision himself as a community leader and policymaker, nor would he be as likely as the full-time attorney to respond to the expectation imposed upon professionals that they render "public service." Thus, it is understandable that he does not subscribe to additional social science training for public responsibility nearly as often as his full-time counterpart. 
There are unquestionably many other variations in the structure of law practice which exert their influence in intricate, interconnected ways upon lawyers' opinions on legal education. Although the preceding analysis is far from complete, it establishes the fact that the influence of structure on opinion does exist.

\section{Conclusions}

It may be observed that the direction of the statistical tables is almost always the same, although the degree of association is greater in "Southmet" than in "Northtown." A plausible explanation lies in the fact that there is a greater homogeneity within the bar in "Northtown." In "Southmet" one encounters the "corporation lawyer," the "labor lawyer," the "management lawyer," the "defendant lawyer" of the insurance company, and the "plaintiff lawyer" of the injured in tort claims. This type of role specialization is likely to bring with it a crystallization of values and attitudes, especially when it reenforces status differences which are apt to be greater in the metropolis than in the small town. Greater role specialization also suggests a reason why Table IV shows a higher degree of association between status of family of orientation and response to the schedule question in "Northtown" than in "Southmet." It would seem that in the relative absence of influences stemming from the contingencies of law practice, the influence of class-rooted attitudes is stronger.

Despite the plausibility of this interpretation, our conclusions regarding the schedule question will be based solely upon the "Southmet" responses. These may be generalized with confidence only to large, possibly only Southernregion, cities. The criticisms of legal education obtained from "Northtown" attorneys are not known to be representative at all. With these qualifications in mind let us summarize the findings:

1. The bars of the two communities investigated were about equally divided concerning the proposition that the law school should give increased attention to education for public responsibility, although there is evidence that nearly all respondents believe this to be part of their professional obligation.

2. The distribution of positive and negative reactions to this proposition is not random, but constitutes a pattern that is comprehensible in sociological terms. The factors which account in major part for this distribution are of two general types: (a) those dealing with socio-economic background and social-political value orientation, and (b) those relating to professional experience and certain structural features of professional practice. If our analysis is substantially correct, we should be able to predict that the lawyer of "liberal" social-political orientation, who is not a member of a firm, who has engaged in political activity, whose occupation is exclusively or almost exclusively the practice of law, and who has a relatively broad definition of the lawyer role (including the element of obligation to perform public service) would favor greater use of social science materials in an expanded program of training for public responsibility. Opinion on law school training for public 
responsibility seems not only to be the product of rational thought process, but seems also to be strongly influenced by these attitudinal and situational factors. This is as obvious as it is difficult to verify, but it is systematically ignored at the higher levels of debate over the future of legal education.

3. The consensus among "Northtown" lawyers concerning legal education is that the law school has been deficient in training its students for many of the exigencies of practice. Not only has it failed to provide adequate training in the mechanics of procedure, but it has also failed to sensitize students to the problems of interpersonal relations in the practice of law, let alone instruct them in the disciplines related thereto, c.g., applied psychology, or applied sociology.

What are the implications of these data and their analysis for legal education? First of all, if any of the factions engaged in disputing the ends and means of legal education wishes to enlist the support of the rank and file lawyer, it must recognize the importance of the kinds of social factors discussed above in the formation of opinion on the subject. In many ways, this tends to place limitations on the effectiveness, and, indeed, even the cogency of purely logical arguments.

Secondly, if those who influence the policy of legal education subscribe to the idea that the law school curriculum should be adapted to the present and predictable needs of all major types of lawyers, they might well scrutinize the needs of the types with which this paper is concerned, since they are in some degree representative of the numerically most significant element in the American bar. Are these lawyers actually policy-makers or policy-advisors? If so, do they need formal training for the kinds of policy-making they engage in? On the other hand, are some of them so inept technically upon graduation from law school that they seriously damage their unwitting first clients' causes-and perhaps even their own reputations?

Finally, the substance of this paper could readily be construed as an argument against the effort to develop a single, multi-purpose curriculum, mode of instruction or training institution to provide optimum training for performance in each of the varied roles performed by lawyers today. It is doubtful, at any rate, whether the trend toward specialization can be reversed. Instead, the legal educator might do well to examine the various possibilities for educating different men for different jobs-the world planner, the estate planner, and the fellow who, in the words of Professor J.IV. Moore, will have to replevy a cow back in his home town. 


\section{THE YALE LAW JOURNAL}

\begin{tabular}{lll}
\hline Volume 64 & FEBRUARY, 1955 & Number 4 \\
\hline
\end{tabular}

EDITORIAL BOARD

Jerome A. Cohen

Editor-in-Chief

BARRY R. BRYAN

Article and

Book Review Editor

Irving J. Alter

Peter W. Anson

Robert W. BEREND

DaNiEL M. Berger

MurRy D. Brochin

Richard C. CaHN

Thomas N. Carruthers, Jr.

Donald J. Cohn

John W. Colleran

Alan P. Colodny

EdMund V. Conway

Gerald M. Doppelt

DAVID A. DREXLER

S. Gordon Elkins

JOSEPH M. FIEID

BARRY H. GarFINTEL
William H. Dempsey, JR, Gerald Walpin

Thomas F. NELSON Managing Editor

Gordon B. Spivack

Note and Comment Editors

Charles S. haiget, Jr. Stephen J. Pollak

ROBERT J. Harris

George C. Hastings

Ira Michael Heyman

Alexander P. HoffMann

Charles D. Isaac

David B. Isbell

LAWRENCE R. KLEIN

Charles S. Mechess, Jr.

Ralph C. Menapace, JR.

Edward A. MiLLeR

JoN O. NewMAN

LaWrence NewMan

MARTIN OPPENHEIMER

Otis P. Pearsall

Richard H. Pershan
Marvin N. RimM

BERNARd S. RODDINS

Norbert A. Schlet

Raymond M. SHainderg

WALTER E. SHutTLEWORTII

Jeanne Ritchie Silver

Monroe Silveraran

ROBERT J. Sisk

ARLEN SPECTER

Melvin Stein

JoHN T. Subak

Charles H. Vejvoin

ROGER A. WeLCH

HOWARD P. WILLENS

George C. Zachary

Marie McMahon

Business Secretary

\section{CONTRIBUTORS TO THIS ISSUE}

PAUL S. TAYlOR. B.A., 1917, University of Wisconsin; M.A., 1920, Ph.D., 1922, University of California. Professor of Economics and Chairman, Department of Economics, University of California. Consulting Economist, Department of the Interior, 1943-52. Author, various books on agricultural labor, articles on reclamation in various periodicals.

Samuer J. Stoljar. LL.B., 1946, LL.M. 1947, London University; Ph.D. 1954. Of Gray's Inn, Barrister-at-law. Senior Fellow and Lecturer in Law, Australian National University, Canberra, A.C.T.

Leonard H. Goodman. B.A., 1949, University of Connecticut; M.A. 1952, Columbia University. Research Assistant, Survey of the Legal Profession, 1951. Instructor in Sociology and Anthropology, University of Delaware.

Richard W. Rabinowitz. B.A., 1947, LL.B., 1950, M.A., 1951, Yale University. Social Science Research Council Fellow, Harvard University, 1951-52. Ford Foundation Board on Overseas Training and Research Fellow, 1952-54. Adviser to Program of Intellectual Cooperation Between American and Japanese Law Faculties, Harvard Law School. 